\title{
Agribusiness Financing Issues: Assessment Features
}

\author{
Bondarenko T.G.* \\ Basic Department of International Law, Finance and \\ Economics of China \\ Plekhanov Russian University of Economics \\ Moscow, Russia \\ e-mail: t.g.bondarenko@gmail.com
}

\author{
Bolvachev A.I. \\ Department of Finance and Prices \\ Plekhanov Russian University of Economics \\ Moscow, Russia \\ e-mail: Bolvachev.AI@rea.ru
}

\author{
Shemetkova O.L. \\ Financial Faculty \\ Plekhanov Russian University of Economics \\ Moscow, Russia \\ e-mail: Shemetkova.OL@rea.ru
}

\begin{abstract}
The article studies difficulties and features of providing loans to agro-industrial enterprises. For all subjects of the market sector, in order to carry out a financial and economic analysis of their activities, there is a special accounting procedure. The authors identified stages of monitoring and provided examples of four legal entities to evaluate the activities of borrowers. The results are presented as examples of reflection of individual articles reporting on the activities of subjects of the agro-industrial industry. Special attention should be paid to the qualitative risk analysis; the authors have developed a risk structure for the activities of agro-industrial enterprises, which reflects their specific features, the level of significance of risk impacts, and the likelihood of occurrence. An analysis of the risk structure allows us to find ways to manage risks.
\end{abstract}

Keywords - financing; agro-industrial complex; lending; leasing, risks.

\section{INTRODUCTION}

Currently, the agricultural sector is increasing soft loans, which is confirmed by farmers believing that an effective form of the government support is to receive loans at low interest rates.

Despite the fact that the demand for loans is fully satisfied, the real interest rate is in a high price range. Therefore, the success of the agro-industrial complex is largely dependent on the government support. To improve the situation in the agribusiness, specialized targeted programs for business sectors are required [1].

Government loan programs are an excellent tool to support agricultural enterprises, develop their potential and competitiveness in the market [2].

According to the surveys, farmers said that an effective form of the government support for the agro-industrial complex is loans at low interest rates [3].
This financing system is the most profitable for large agricultural holdings. It is difficult for small farmers to take advantage of the program of preferential lending, since their main problem is the lack of a collateral base; therefore, it is necessary to consider the possibility of using a commodity lending form [4].

In this case, there is a possibility of using leasing activities as a source of financing for agricultural enterprises and farmers. Today, leasing as a market phenomenon is a soughtafter financial instrument - new market participants have appeared, and the legislative framework is being improved. Fortunately for agrarians, leasing became an integral part of the agricultural sector [5].

The main advantages of the leasing system are as follows:

- leased property is on the balance sheet of the lessor, i.e., it does not increase accounts payable and the amount of property tax;

- depreciation and repair of equipment is carried out by a leasing company;

- VAT refunds;

- the opportunity to take advantage of the program for subsidizing agricultural equipment manufacturers, i.e., to receive an additional discount;

- the possibility of leasing several units of equipment, which is especially important for large agricultural holdings;

- a flexible payment schedule taking into account the specifics of activities of agricultural enterprises (including the seasonality of payments).

The advantages of leasing are the possibility of applying an accelerated depreciation coefficient and the minimum amount of investment at the initial stage. That is why leasing 
transactions will be of interest to both suppliers and leasing companies, and their customers, lessees: now the number of proposals for the purchase of equipment with the possibility of subsidies from the manufacturer is increasing.

The main factors for approving a loan are the financial condition of the client - the ability to adapt the loan amount and the number of tranches, the availability of additional guarantees, and the absence of litigation.

Currently, the agricultural industry is developing due to the government support and an inertia way of doing business, banks and credit organizations provide farmers with resources through the use of various tools and methods, as well as take into account features of this business (time intervals for profitability, performance calculations, feasibility of providing cash in requested periods, payback calculations, conditions for business activities). [6].

\section{FEATURES OF FINANCIAL AND ECONOMIC ANALYSIS OF ACTIVITIES OF AGRICULTURAL ENTEPRSIES}

\section{A. Specific Features of the Agricultural Industry}

According to its content and objectives, the analysis of economic activities in the agro-industrial complex (AIC) is similar to the analysis in other sectors of the national economy [7]. A financial analysis of agribusinesses is carried out only on the basis of official reporting; a prospective cash flow statement is generated for any analysis purpose.

However, the methodology for its implementation has some differences (for example, compilation of a retrospective report of cash flows is not required), due to the following specific features of this industry:

- activities are highly dependent on external factors: economic, weather, political;

- significant differences for the sub-sectors (crop production, animal husbandry, poultry farming, etc.);

- a long production cycle, a discrepancy in time between the period of incurring costs and generating income, the cyclical nature of production, the uneven use of resources;

- $\quad$ seasonal;

- products are often used for own needs (feed grain, repair herd), can transfer from inventory (fixed assets) to fixed assets and vice versa, increase in volume and value disproportionately to costs (depending on the yield, gain, etc.);

- barter transactions are used;

- a low degree of automated accounting and reporting.

A separate element of the analysis is the tax system used for a particular agribusiness entity.

It is also necessary to remember about subsidies to agribusiness entities [8], which affect the final financial result of their activities reflected in the statement of cash flows and the "Financial income" section under the article "Target government financing". The procedure for granting subsidies is determined by target programs or additional regulatory acts of executive authorities.

The starting point for the analysis of financial and economic activities is the production cycle - for example, for crop production, this is the period during which the crop was harvested and all expenses incurred for preparing the land, growing and harvesting the crop. The main stages of the production cycle are as follows:

- $\quad$ pre-sowing tillage, preparatory works;

- $\quad$ sowing;

- treatment;

- harvesting.

The structure and duration of the production cycle depend on the type of production [9], the level of organization of the production process and other factors [10]. Depending on the region, the duration and specificity of the production cycle can vary [11].

For all subjects of the agro-industrial complex, in order to carry out a financial and economic analysis of their activities, a special accounting procedure is used. When considering the results of activities of agribusiness entities, a report is generated for 12 months, with a changing seasonality. It can be generated for 36 months. In this case, a report is generated monthly for the last 12 months, and quarterly for the remaining 24 months.

Based on the results of the financial and economic analysis, a forecast cash flow statement (FCFS) is compiled. Traditionally, when monitoring activities of agricultural enterprises, an analysis is of deviations of actual performance from previously planned one is carried out and influence factors and their valuation in the structure of the reports are determined.

\section{B. Results of the analysis of accounting of agricultural activities}

- Les us analyze example 1

The company cultivates 3 crops: winter wheat, safflower and sunflower.

Over the past 3 years, the yield of winter crops is higher than the average annual productivity by $15 \%$, safflower - by $25 \%$, sunflower - by $40 \%$. Moreover, the revenue structure for 12 months is as follows: winter wheat $(67 \%)$, safflower (23\%, sunflower $(10 \%)$

The employee of the financial and planning department:

- determines the deviation in yield for each crop separately: Winter wheat $-15 \%$, Safflower $-25 \%$, sunflower - $40 \%$;

- Adds shares in revenue for crops for which the yield exceeded $20 \%: 23 \%$ (Safflower) $+10 \%$ (sunflower) $=33 \%$; 
- determines the analysis period: the analyzed period is 36 months, because the share in crop revenue for which a deviation in yield of more than $20 \%$ is recorded is $33 \%$ (more than $30 \%$ ).

The volumes of monthly sales / costs are determined by distributing the total revenue / costs for monthly periods in proportion to the dynamics of the analyzed period. In the absence of a retrospective ODDS, the monthly distribution is proportional to the dynamics of the revenue of the company for the last 12 months, but another distribution by months in the forecast period is possible, if there are changes in the micro and macro environment.

For example, the receipt of money from buyers can be checked in such a way that takes into account the volume of unsold products of the completed production cycle, multiplied by the forecast sales price, to which the planned volume of sales of the current / future production cycle, also multiplied by the forecast sales price, is added. The retroactive calculation calculation of payment to suppliers - takes into account the planned costs of the crop for the current / future production cycles, the estimated reduction in debt to suppliers minus the estimated increase in debt to suppliers (if any), as well as the amount of costs for the incomplete production cycle.

It should be borne in mind that for enterprises with a working herd cycle of less than 12 months (since the birth of animals to their sale), sales data are analyzed monthly.

For enterprises with a working herd cycle of more than 12 months, sales data are analyzed for 18 months prior to the date of the financial analysis on a monthly basis.

- Let us analyze example 2 .

An agricultural company (cattle breeding) sends gobies aged 18 months for slaughter. This means that in the analyzed period (12 months), the the company can sell only bulls, which at the time of the financial analysis will be 6 months or more. The livestock includes 1000 animals. The average price of one animal is 50,000 rubles.

The calculation of maximum profit is determined by formula: $1000 * 50000 \mathrm{rub} .=50000000 \mathrm{rub} / \mathrm{year}$.

- Let us analyze example 3.

The company is engaged in sheep farming. In the retroperiod, it sold $30 \%$ of lambs aged 3 months (dairy) and $70 \%$ of lambs aged 18 months.

The company uses simultaneous insemination, i.e. offspring is expected in March-April. Each bright brings one lamb. The number of queens is 2,000. January will be the month of the financial analysis, which means that in the forecast period the company will be able to sell all the lambs that were grown for slaughter (except for those selected for repair herds) $+30 \%$ of the lambs born in March. The average selling price of a milk lamb is 4,000 rubles, and a lamb aged 12 months is 5,500 rubles.

The calculation of the maximum sales volume should be contained in the comments on the cash flow forecast of the company.
In dairy cattle breeding, fleece sheep breeding, egg and hatchery poultry farming and other types of livestock breeding involving the sale of products produced by animals of the main herd, the calculation has the following form:

- revenue is forecasted taking into account the output in the retro-period calculated per one head of the main herd (milk yield, egg production, wool weight, etc.) according to the formula for the product of the number of heads of the main herd on the date of the financial analysis and the output per 1 head.

- when calculating the maximum possible sales volume, it is necessary to multiply the productivity of the main herd by the selling price of a unit of production. At the same time, the productivity of the main herd (milk yield, egg laying, wool cutting) must be compared with average values for the breed given in the reference tables from open sources (Internet, media, etc.), with a link to the information source. If there are deviations of more than $10 \%$, comments on increased / reduced performance are required.

- Let us analyze example 4.

Let us calculate the maximum possible sales volume using the example of a turkey breeding farm. Table 1 is filled out for the activities of this enterprise. Let us take into the category "Females of the parent herd", the egg production of 1 unit is 18 pcs. per year, hatching of eggs is $80 \%$, the period of complete renewal of the main herd is 12 months.

In April-August, the company will sell one-day chickens. In accordance with the planned indicators, during the incubation process, the enterprise receives 108,000 eggs $(6000 * 18)=108,000$ pcs. No eggs are sold; all eggs are incubated. During the incubation, 86,400 turkeys hatch $(108,000 * 0.8)$.

It is known that $80 \%$ of offspring are sold per diem, i.e. $86,400 * 0.8=69,120$ birds. Price of 1 one-day chicken is 200 rubles. Therefore, in March-August, the company can receive an income of $69,120 * 200=13,824,000$ rubles.

In September-October, the main herd is replaced by the repair young herd. Because the main herd is completely updated, in this period 4,000 birds are slaughtered. The average price of one carcass is 1,900 rubles. Therefore, in September-October, the enterprise can receive an income of $6,000 * 1,900=7,600,000$ rubles

In November and February, the herd is fed.

$$
86400-69120=17,280
$$

(left after the sale of one-day chickens)

$17,280-12,000$ (left in the repair herd) $=5,280$ birds

In November-February, the company can receive an income of $5,280 * 1,900=10,032,000$ rubles.

In January-March, the income is generated by slaughtering the repair herd.

$$
12000-4000=8000 * 1900=15,200,000 \text { rubles } .
$$


Similarly, taking into account the number of birds in the main / repair / working herd and costs per 1 bird, the periods in which this or that livestock is kept, the volumes of payments are checked. The consolidated calendar plan of the company is presented in Table 2 .

TABLE I. LIVESTOCK STRUCTURE IN POULTRY FARMING OF AN AGRICULTURAL ENTEPRISE

\begin{tabular}{|l|l|l|l|}
\hline Livestock (groups) & $\begin{array}{c}\text { The number of } \\
\text { goals at the } \\
\text { date of the FA, } \\
\text { pcs }\end{array}$ & $\begin{array}{c}\text { Maximum } \\
\text { number of } \\
\text { goals in a } \\
\text { group, year }\end{array}$ & $\begin{array}{c}\text { Average cost } \\
\text { of feeding of } \\
\text { one goal per } \\
\text { month, rubles. }\end{array}$ \\
\hline Main herd the & 4000 & 6000 & 130 \\
\hline $\begin{array}{l}\text { Females of } \\
\text { parent herd }\end{array}$ & 6000 & & \\
\hline Female laying hens & 0 & 000 & 140 \\
\hline Males & 0 & 6000 & 140 \\
\hline Working herd,pcs & 2000 & 12000 & \\
\hline Repair herd, pcs. & 4000 &
\end{tabular}

TABLE II. CALENDAR PLAN OF THE TECHNOLOGICAL PROCESS OF AN

\begin{tabular}{|c|c|c|c|c|c|c|}
\hline \multirow{2}{*}{$\begin{array}{c}\text { Name of the stage } \\
\text { of the } \\
\text { technological } \\
\text { process }\end{array}$} & \multicolumn{6}{|c|}{ Months } \\
\hline & 01 & 02 & $\mathbf{0 3}$ & 04 & 05 & 06 \\
\hline $\begin{array}{l}\text { Keeping of the } \\
\text { main herd }\end{array}$ & & $\mathrm{v}$ & $\mathrm{v}$ & $\mathrm{v}$ & $\mathrm{v}$ & $\mathrm{v}$ \\
\hline $\begin{array}{l}\text { Egg production of } \\
\text { the main herd }\end{array}$ & & & $\mathrm{v}$ & $\mathrm{v}$ & $\mathrm{v}$ & $\mathrm{v}$ \\
\hline $\begin{array}{l}\text { Purchase of eggs } \\
\text { and laying for } \\
\text { incubation }\end{array}$ & & & & & & \\
\hline Sale of eggs & & & & & & \\
\hline $\begin{array}{l}\text { Sale of one-day } \\
\text { chickens }\end{array}$ & & & & $\mathrm{v}$ & $\mathrm{v}$ & $\mathrm{v}$ \\
\hline $\begin{array}{l}\text { Sale of grown } \\
\text { chickens }\end{array}$ & & & & & & \\
\hline $\begin{array}{l}\text { Keeping of repair } \\
\text { birds }\end{array}$ & $\mathrm{v}$ & $\mathrm{v}$ & & & & \\
\hline $\begin{array}{l}\text { Exclusion of repair } \\
\text { (1) and rejected } \\
\text { chickens of the } \\
\text { main herd (2) }\end{array}$ & v 1 & v 1 & v 1 & & & \\
\hline $\begin{array}{l}\text { Slaughter of young } \\
\text { birds (broilers, etc.) }\end{array}$ & $\mathrm{v}$ & $\mathrm{v}$ & & & & \\
\hline $\begin{array}{l}\text { Name of the stage } \\
\text { of the } \\
\text { technological } \\
\text { process }\end{array}$ & 07 & 08 & 09 & 10 & 11 & 12 \\
\hline $\begin{array}{l}\text { Keeping of the } \\
\text { main herd }\end{array}$ & $\mathrm{V}$ & $\mathrm{v}$ & & & & \\
\hline $\begin{array}{l}\text { Egg production of } \\
\text { the main herd }\end{array}$ & $\mathrm{v}$ & $\mathrm{v}$ & & & & \\
\hline $\begin{array}{l}\text { Purchase of eggs } \\
\text { and laying for } \\
\text { incubation }\end{array}$ & & & & & & \\
\hline Sale of eggs & & & & & & \\
\hline $\begin{array}{l}\text { Sale of one-day } \\
\text { chickens }\end{array}$ & $\mathrm{v}$ & $\mathrm{v}$ & & & & \\
\hline $\begin{array}{l}\text { Sale of grown } \\
\text { young birds }\end{array}$ & & & & & & \\
\hline $\begin{array}{l}\text { Keeping of repair } \\
\text { birds }\end{array}$ & & $\mathrm{v}$ & $\mathrm{v}$ & $\mathrm{v}$ & $\mathrm{v}$ & $\mathrm{v}$ \\
\hline $\begin{array}{l}\text { Exclusion of repair } \\
\text { (1) and rejected } \\
\text { chickens of the } \\
\text { main herd (2) }\end{array}$ & & & v 2 & v 2 & & \\
\hline $\begin{array}{l}\text { Slaughter of young } \\
\text { birds (broilers, etc.) }\end{array}$ & & & & & $\mathrm{v}$ & $\mathrm{v}$ \\
\hline
\end{tabular}

Payments to suppliers and payments from buyers can be adjusted downward by the amount of a decrease / increase in debts to buyers / suppliers (if there are preconditions) [12].

\section{The strucure of AIC risks}

It is necessary to analyze the following risks.

- Marketing (sales) risks. The wrong choice of sales markets can be described as a risk with a critical assessment of the impact, however, these risks are low for the enterprise due to the experience of a project initiator [13]. The risk of a drop in demand (as a result, a decrease in sales) has a significant impact assessment, but it can be characterized as moderate, since the products used in the production of food products are consumed by the population. The risk of competition also has a significant impact, but its development is unlikely due to the high capital intensity.

- Technical risks. Errors in design have a significant impact, but their probability is not high, as professional design companies will be involved. Delays in the design and construction of buildings also have a significant impact, the probability of their occurrence is average, since it is usually planned to involve professional construction organizations, but there may be difficulties with communication systems. Failure to fulfill the obligations undertaken by partners (general contractors, suppliers) has a significant impact assessment, but a low probability of occurrence, since costs of construction and installation works are usually fixed. Rising prices have a significant impact, taking into account the macroeconomic and political instability, the risk is average.

- Technological risks. Low-quality output has a significant impact. The risk of product quality is important, the probability is moderate due to the availability of own laboratory, quality control of finished products, advanced equipment. An increase in fuel and energy prices is characterized by an average impact rating. Due to the monopoly of energy suppliers, an increase in prices can be considered reliable. The probability of such a risk is close to $100 \%$. An increase in salary costs is also characterized by an average impact rating. The probability of occurrence of these risks is minimal, because when determining the level of wages. Conflicts with the company personnel are unlikely.

- Financial risks have a significant impact. Interest rate risks have a minimal probability of occurrence, but lead to an increase in interest costs. Currency risks (changes in the exchange rate) are significant, since the ruble exchange rate depends on fluctuations in oil prices. Political risks are characterized by the value of imports and determined by customs duties. The risk of a shortage of working capital has an average probability of occurrence, since the norms of working 
capital are calculated on the basis of own estimates. Separately, the inflationary risk can be mentioned, since all financial calculations are based on current prices, taking into account inflation, but the real level of inflation may be different from the planned one.

- Environmental risks. Damage to the environment is significant. This risk has a low probability, since production does not have a significant negative impact on the environment. Production waste is not hazardous.

- Administrative risks. The likelihood of a risk is insignificant, since this project will help strengthen the economy of the city and region, increase the number of jobs and tax revenues. If the project is included in the list of priority projects, local and regional authorities will support it.

\section{CONCLUSION}

The analysis of the risk structure allowed us to find ways to manage risks. For example, sales risks can be managed through proactive development of the customer base, diversification of sales, expansion of the sales market, formation of dealer networks, price monitoring, and price reduction.

Production risks are controlled by creating additional reserves, redistributing risks to equipment suppliers, builders, using legal and financial levers to control and manage the project, and increasing exchange rates and prevailing deflator indices. In addition, it is necessary to take into account that the current activity of the project is ensured by contractual relations with energy suppliers, and all calculations are based on current prices and take into account possible price changes and deflator indices [14].

Financial risks are controlled due to the structure and costs of borrowed funds, taking into account the forecast changes in the exchange rate (for example, if the exchange rate decreases critically, production volumes will decrease [15]). In addition, there are expenses for covering the deficit of working capital. Expenses are optimized, and part of the claim is transferred to the buyers.

Legal risks are minimized with the help of third-party legal organizations that control all project documents, contracts concluded with suppliers of raw materials and buyers of final products.

\section{References}

[1] T.P. Maksimova, K.V. Milyaev, "Institutional Features of Cluster Development in the Russian Federation", Int. Rev. of Manag.t and Market., vol. 6, no. S6, 2016.
[2] S.F. Khasanova, A.I. Fazullina, "Assessing of the competitiveness level in the industry using the correlation analysis on the example of agriculture of the republic of Tatarstan, Russian Federation, New York", Amer. J. of Agricult. and Biolog. Sci., vol. 10, no. 1, 2015 DOI: 10.3844/ajabssp.2015.12.17

[3] R.S. Zhussupov, R.A. Baizholova, I.N. Dubina, G.T. Sadykova, "Methodology for assessing the competitive advantages of agriculture in the northern regions of Kazakhstan", Revista ESPACIOS, no. 16, p. 39 2018. Retrieved from: http://www.revistaespacios.com/a18v39n16/ 18391646.html

[4] N.E. Bondarenko, T.G. Bondarenko, L.V. Goryainova, T.P. Maksimova, O.A. Zhdanova, "Development financing of the subjects of Russian agro-industrial complex", Int. J. of Mechan. Engineer. and Technol., vol. 9, no. 8, pp. 1187-1197, 2018

[5] N.R. Amirova, L.V. Sargina, "Price disparity as a factor underlying the current downturn in Russia's agrarian economy", Int. J. of Econ. Res. vol. 13, no. 9, pp. 3747-3757, 2016. Retrieved from: www.serialsjournals.com

[6] T.G. Bondarenko, T.P. Maksimova, O.A. Zhdanova, L.V. Goryainova N.E. Bondarenko, "Financing small forms of management in the agroindustrial sector", Int. J. of Mechan. Engineer. and Technol., vol. 9, no. 8, pp. 1228-1233, 2018.

[7] V. Kolmakov, K. Ekimova, K. Ordov, A. Aliev, N. Tchuykova "Monetary Policy Influence on Companies' Competitiveness through Credit Channel”, Europ. Res. Stud. J., vol. 2, pp. 614-623, 2018.

[8] T.P. Maksimova, N.E. Bondarenko, "Development of inter-firm cooperation in the Russian agro-industrial complex: Theory and practice", Espacios, vol. 38, no. 33, art. 15, 2017. Retrieved from: http://www.revistaespacios.com/a17v38n33/a17v38n33p15.pdf

[9] D. Hayati, Z. Ranjbar and E. Karami, "Measuring agricul-tural sustainability", ed. E. Lichtfouse, 2010, Biodiversity, Bio-fuels, Agroforestry and Conservation Agriculture, 73, Sustain-able Agriculture Reviews 5, Springer Science+Business Media B.V., 73-100. DOI: 10.1007/978-90-481-9513-8_2

[10] K. Anderson, A. Strutt, "The changing geography of world trade: Projections to 2030", J. of Asian Econ., vol. 23, no. 4, pp. 303-323, 2012. DOI: 10.1016/j.asieco.2012.02.001

[11] A.Z. Seleznev, L.G. Cherednichenko, M.V. Dubovik, A.V. Sigarev, "Budgetary policy as a tool of macroeconomic regulation of the economy and social sphere", J. of Advan. Res. in Law and Econ., vol. 7 no. 7, pp. 1845-1853, 2016. Retrieved from: http://journals aserspublishing.eu/jarle/issue/archive. Doi: 10.14505/jarle.v7.7(21).32

[12] A. Sergeyevich Baleevskikh, M. Mirsayafovich Galeev, "Strategy and tactics for improving competitiveness of the products of agro-industrial complex", World Appl. Sci. J., vol. 18, pp. 150-153, 2012. Retrieved from: http://idosi.org/wasj/wasj18(Economics)12/24.pdf Doi: 10.5829/ idosi.wasj.2012.18.120024

[13] V. Sachitra, S.-C. Chong, "Resources, capabilities and competitive advantage of minor export crops farms in Sri Lanka: An empirical investigation", Competitiveness Rev., vol. 28, no. 5, pp. 478-502, 2018.

[14] H. Bachev, "Sustainability of Bulgarian farming enterprises during European Union common agricultural policy implementation", J. of Appl. Econ. Sci., vol. 12, no. 2, pp. 422-451, 2017. Retrieved from: http://www.cesmaa.eu/journals/jaes/files/JAES \%20Spring \%202(48) $\% 20 X I I \% 202017$ online.pdf

[15] M. Brockmeier, J. Pelikan, "Agricultural market access: A moving target in the WTO negotiations?", Food Policy, vol. 33, no. 3, pp. 250-259, 2008. DOI: 10.1016/j.foodpol.2007.10.006 